\title{
Gold in the Late Roman Empire
}

\section{A GOLDSMITH'S WORKSHOP IN ROMAN BRITAIN}

\section{Peter A. Clayton}

British Museum Publications Limited, London

A major exhibition, "Wealth of the Roman World", open from April 1st to October 1st at the British Museum, illustrates through the medium of gold and silver objects the rise and fall of prosperous civilisations through the years A.D. 300 to 700. With this as his background, the author describes a unique inscription associated with a goldsmith's workshop and the social conditions which this indicates.

In A.D. 300 there was a single Roman Empire. Four hundred years later three major spheres of power had emerged: the late Roman Empire of Byzantium, the Arab Caliphate (with the rise of Islam in the sixth century) and the Germanic kingdoms of the north and west. With the exception of coins, more silver than gold has survived from this period, and most of the gold comes largely from official workshops in important centres. Under some of the Emperors such as Anastasius there are official workshop stamps sometimes found on the objects, but smaller and more personal items would have been the products of more local craftsmen, including those on the very fringes of the Roman world such as Britain.

Gold, apparently mostly of Irish origin, is relatively plentiful in finds from Bronze Age Europe, but objects of gold from Roman Britain are comparatively scarce. In May of 54 B.C., the year of Caesar's second expedition against Britain, Cicero wrote to his friend Trebatius Testa in Gaul (1):

"In Britannia nihil esse audio neque auri neque argenti."

(I believe there to be nothing in Britain, neither gold nor silver)

A relief showing Roman gold minerg on their way to work. Found near Linares in Spain, this dates from about the first century A.D., and is now in the Berghaumuseum at Bochum in West Germany
Strabo, writing shortly after the death of Augustus in A.D. 14, listed the exports from Britain as corn, cattle, gold, silver, iron, hides, slaves and hounds (2) -a very comprehensive list for an island that was not to become a Roman province until the invasion of the emperor Claudius in A.D. 43.

Subsequently extensive Roman lead workings, silver being a by-product, are known in the Mendips, in Derbyshire, in Northumberland and in Yorkshire and, judging from the official stamps that occur on a number of the pigs of lead found, all the workings were under Imperial control or at least closely supervised from that quarter.

Only one gold mine is known so far in Roman Britain at Dolaucothi, near Pumpsaint, in Carmarthenshire. This site, extending over an area of about 


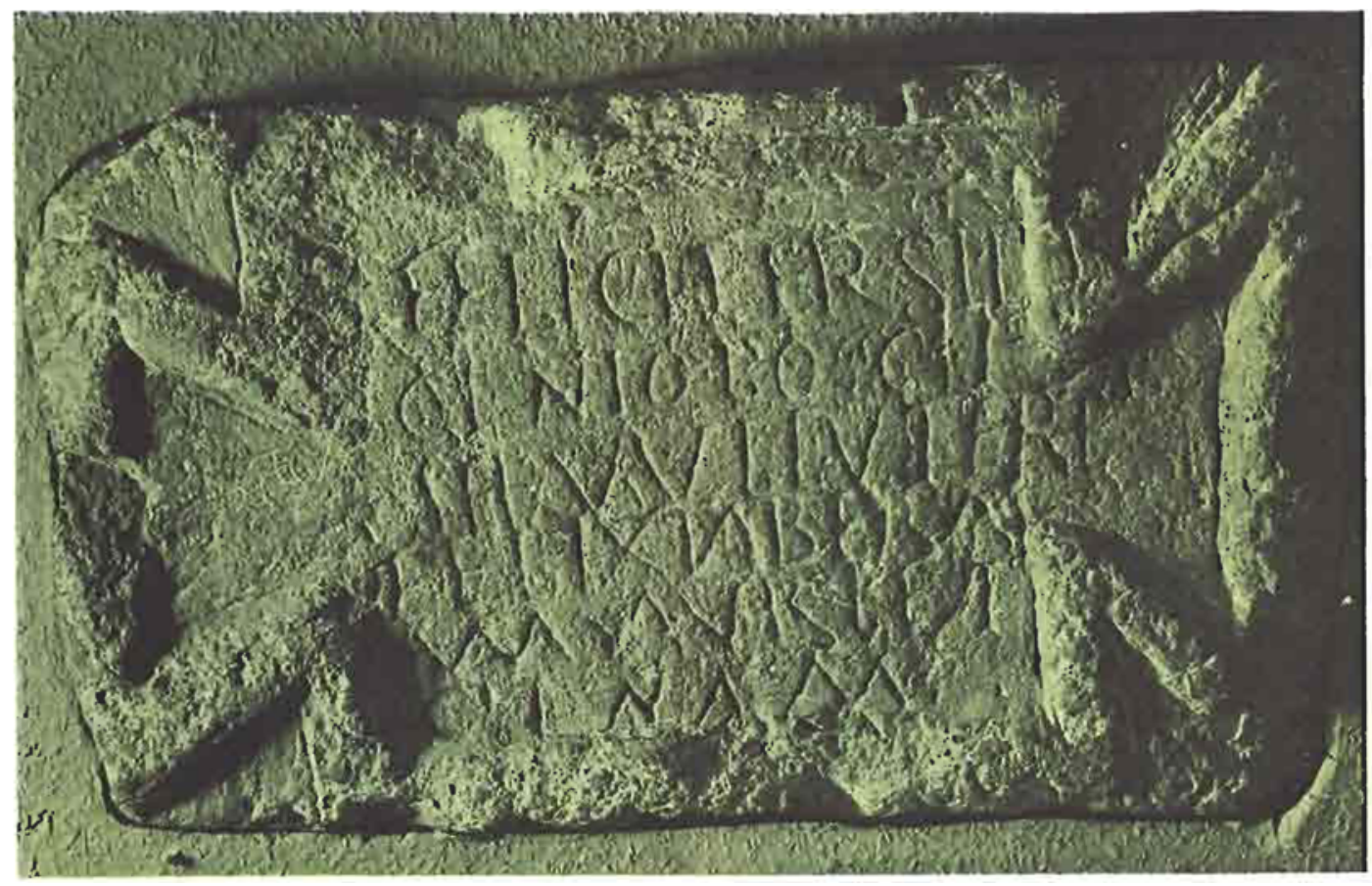

A Roman building stone found at Malton in Yorkshire in 1814. The inscription, the only one of its kind so far discovered, wighes good fortune to the young slave in clarge of a goldsmith's workshop in the civilian settlement outside the fort of Derventio. It can be dated to around the end of the third or the beginuing of the fourth eentury A.D. Photograph by courcesy of the Yorkshire Museum

a square mile, has produced evidence of extremely sophisticated mining and working techniques in the Roman period. Water was needed in the process and was brought seven miles by a rock-cut aqueduct from the river Cothi. The whole industrial complex was on a huge scale, and very evidently under tight Imperial control. Roman army engineers seem to have been responsible for the high quality of the work. The Second Cohort of Asturians formed the garrison of the fort at Llanio, ten miles away; their home area in Spain was an important gold-bearing district and so presumably their posting to the Dolaucothi area was no accident.

Evidence for goldworking, such as crucibles with residues of gold, has been found at Cirencester, London and St Albans (3); far less than might be expected from Roman Britain. The strongest evidence for the use and knowledge of goldworking technology in Roman Britain is from London in the gold aureii struck at the mint there during the reigns of the usurper emperors Carausius (A.D. 286-293) and Allectus (A.D. 293-296). These coins carry a series of mintmarks containing the letter L (for Londinium) in combinations such as ML, MLX, MSL,and SML.

Despite all this circumstantial evidence for gold working in the coins and jewellery finds it is curious that from among the several thousand inscriptions known from Roman Britain only one refers to a goldsmith's shop.
In 1814 a small Roman building stone $(13 \times 8$ inches) was discovered when the foundations for a new church were being laid at Norton, on the other side of the river Derwent from Malton, 18 miles north-east of York. Malton was the site of the Roman fort of Derventio, and the inscribed slab came from the area outside the fort known as the vicus, the civilian settlement often found adjacent to forts. Within an ansate panel is a roughly cut inscription in six lines with rather arbitrary word breaks. It reads:

\section{FELICITER SIT/GENIO LOCI/SERVULE UTERE FELIX TABERNA/M AUREFI/CINAM}

This has been translated as "Good luck to the Genius of this place. Young slave, use to your good fortune this goldsmith's shop" (4). An alternative version has it as "Good luck to the Genius of this place! Good luck to you, young slave, in running this goldsmith's shop" (5). Whichever translation is preferred, two major elements of the inscription remain unaffected: one is the fact that we have here a definite reference to a goldsmith's shop working in the vicus attached to the Roman fort. It is the only known mention of such a shop from Roman Britain to date, but it must be remembered that the stone itself was found accidently and not under controlled excavation conditions, and also that it is only in fairly recent years that any attention has been paid to the excavation of the vicus area found attached to forts. 
A group of Romano-British jewellery comprising two bracelets made by twisting heavy gold wire, two rings and a necklace of gold links, dating from the fourth century A.D. These were probably made by a local craftsman sueh as the goldsmith referred to in the inscription, but they were in fact found near the entrance to the famous passage-tomb of Newgrange erected in Ireland in about 2000 B.C.

Photograph by courtesy of the Trustees of the British Museum

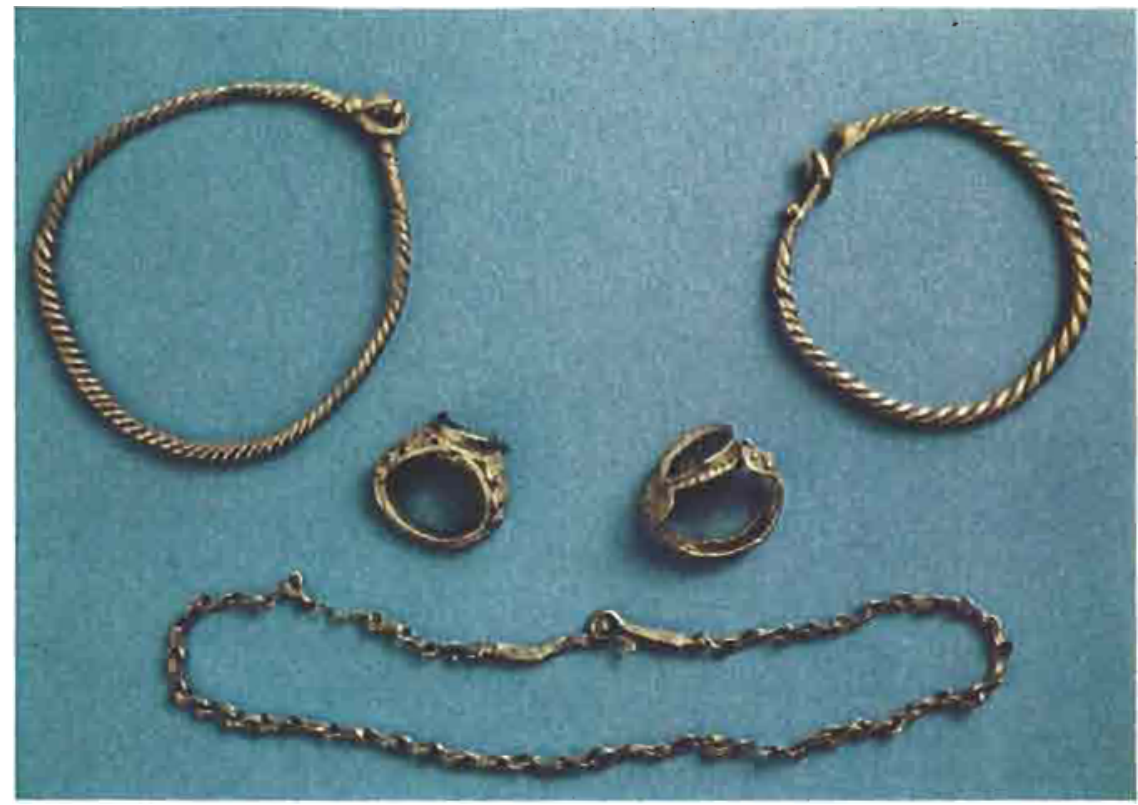

The other salient point of interest is the specific address to the young slave in the inscription. It immediately sheds light on the social side of Roman Britain where slavery was not uncommon. The slave concerned-it is unfortunate that we cannot identify him by name-obviously held a position of trust in the goldsmith's establishment to be mentioned in the same breath as the salute to the genius of the shop. A modern view of slavery can, at times, be very misleading and in all probability this slave, despite his apparent lowly status, held a trustworthy, possibly managerial, post and was almost certainly better off and better cared for than a nominally free man toiling to support himself and his family in Roman Britain.

There is no internal dating evidence on this inscribed building stone, but from excavations that have been carried out in the vicus it would appear that it was most prosperous between about A.D. 200 to 367 (6). Certainly there appears to be plenty of stone buildings roofed with lozenge-shaped stone slates and any workshop that dealt in gold would have to be secure by the very nature of its trading. Hence the goldsmith's shop at Malton can perhaps be placed sometime in the third century or the first half of the fourth century A.D.

\section{References}

1 Cicero, "ad Familiares", VII, 7, 1

2 Strabo, "Geographia", IV, Chapter 5

3 S. S. Frere, "Britannia", London, 1967, p. 259

4 R. G. Collingwood and R. P. Wright, "The Roman Inscriptions of Britain", Oxford, 1965, Vol. 1, Inscription No. 712 ; "Corpus Inscriptionum Latinorum", Vol. VII No. 265

5 L. P. Wenham, "Derventio", (Malton), Huddersfield, 1974, p. 46

6 L. P. Wenham, op. cit., p. 36

COLD, whose Chymical name is Sol, and Mark $\odot$ is said to be of most pure, $\checkmark$ and best prepared Materials, hence it hath many Attributes that transcend other Metalls, as Value, Weight, Duration, Ductility, Attraction, Medicinall Use, etc. It never rusts, nor consumes with often melting; tis only purified, but not consumed; tis indeed dissolveable in Aqua-Regia and that only. It may be beaten or stretched admirably thin.

\section{CHARLES MORTON Compendium Physicae London, I680}

The Compendium Pbysicae was the science text book used at Harvard for about forty years between 1687 and 1728. Charles Morton was an English clergyman, born in Cornwall and educated at Oxford, who emigrated to New England in 1686 to become pastor at Charlestown 